Situs Jurnal : $\underline{\text { http://ejournal.stiepancasetia.ac.id/index.php/iieb }}$

Jilid 6 Nomor 1 Maret 2020

Hal 1-12

\title{
FAKTOR-FAKTOR YANG MEMPENGARUHI MINAT BERWIRAUSAHA PADA MAHASISWA JURUSAN MANAJEMEN \\ FAKULTAS EKONOMI UNIVERSITAS ISLAM KALIMANTAN MUHAMMAD ARSYAD AL-BANJARY BANJARMASIN Periyadi, Sri Bulkia, Risnawati
}

Fakultas Ekonomi, Universitas Islam Kalimantan E-mail : periyadi582@ymail.com

Abstrak: Tujuan utama dalam penelitian ini adalah untuk mengkaji dan menganalisis (1) Bagaimana faktor -faktor kerwirauasahaan yang terdiri dari lingkungan sosial dan keluarga, inovasi dan kreatif, serta lingkungan teknologi berpengaruh terhadap minat berwirausaha. (2) Bagaimana pengaruh lingkungan sosial dan keluarga terhadap minat berwirausaha. (3) Bagaimana pengaruh inovasi dan kreatif terhadap minat berwirausaha. (4) Bagaimana pengaruh lingkungan teknologi terhadap minat berwirausaha. Adapun target dalam penelitian ini antara lain (1) Dari hasil peneliti ini dapat menjadi masukan bagi peneliti-peneliti lain untuk mengadakan penelitian serupa dimasa yang akan datang. (2) Dapat di gunakan bahan masukan untuk meningkatkan pengembangan minat siswa dalam berwirausaha. (3) Hasil penelitian ini diharapkan dapat digunakan sebagai evaluasi dan informasi yang bermanfaat untuk melakukan perbaikan-perbaikan yang berorientasi pada masa depan, utamanya pada minat siswa dalam berwirausaha. Penelitian ini dilakukan dengan metode kuantitatif serta menggunakan metode analisis dengan SPSS Windows For Data sebagai sebuah alat analisis data.

\section{Kata Kunci : Kewirausahaan, Minat, Faktor.}

\section{Latar Belakang}

Menurut Zuli Purnamawati (2009) menjadi pengusaha merupakan alternatif pilihan yang tepat. Paling tidak, dengan berwirausaha berarti menyediakan lapangan kerja bagi diri sendiri dan tidak bergantung pada orang lain. Seorang wirausahawan adalah seorang yang memiliki keahlian untuk menjual, mulai dari menawarkan ide hingga komoditas baik berupa produk atau jasa.

Seorang wirausahawan (entrepreneur) adalah seseorang yang menciptakan bisnis baru dengan mengambil risiko dan ketidakpastian demi mencapai keuntungan dan pertumbuhan dengan cara mengidentifikasi peluang yang signifikan dan menggabungkan sumber-sumber daya yang diperlukan sehingga sumber-sumber daya itu bisa dikapitalisasikan (Zimmerer, 2008). Dengan kreativitasnya, wirausahawan mampu beradaptasi dengan berbagai situasi dan kondisi lingkungan. Sebagai pelaku bisnis, wirausahawan harus mengetahui dengan baik manajemen penjualan, gaya dan fungsi manajemen.

Di Indonesia saat sekarang ini sangat sulit untuk mendapatkan pekerjaan. Hal ini semakin memperparah keadaan ekonomi bangsa dengan timbulnya penangguran yang ada. Oleh karena itu, di dalam perekonomian negara berwirausaha merupakan alasan betapa pentingnya hal tersebut dikembangkan. Akhirnya, banyak orang yang 
berusaha untuk mendapatkan pekerjaan dengan cara salah satunya adalah mendirikan usaha sendiri atau yang lebih dikenal sebagai berwirausaha.

Indonesia memiliki potensi ekonomi yang besar, dengan kekayaan alam melimpah, penduduk dengan jumlah besar dan tenaga kerja muda yang juga dengan jumlah besar. Ini bisa dilihat populasi penduduk Indonesia yang sekarang sudah 250 juta. Disinilah sebenarnya muncul suatu kesempatan bagi wirausaha baru untuk mengambil peluang ini agar bisa mencapai suatu tujuan wirausaha tersebut. Selain itu, lapangan pekerjaan dari perusahaan perusahaan besar sekarang mulai berkurang, serta banyaknya perusahaan besar yang menerima tenaga kerja dengan sistem kontrak. Oleh sebab itu dengan mempunyai minat untuk berwirausaha maka mendorong terciptanya lapangan pekerjaan baru yang akhirnya menciptakan suatu kemakmuran.

Universitas Islam Kalimantan Muhammad Arsyad Al-Banjary Banjarmasin merupakan salah satu perguruan tinggi swasta yang ada dibanjarmasin memiliki berbagai macam fakultas dan jurusan yang salah satunya adalah fakultas ekonomi jurusan manajemen selalu berupaya untuk tetap dapat melaksanakan tujuan fakultas agar mampu mencapai tujuan dengan baik. Diharapkan mahasiswa mampu membangun jiwa profesionalisme salah satunya membangun jiwa kewirausahaan. Untuk menumbuhkan jiwa berwirausaha dibutuhkan minat dari dalam diri mahasiswa maupun dari luar. Sukirin (1986) menyatakan minat adalah kecenderungan dalam diri individu untuk tetarik pada suatu objek. sehingga minat mengandung unsur keinginan untuk mengetahui dan mempelajari dari sesuatu yang diinginkannya itu sebagai kebutuhannya.

Menurut Erika Agustina (2013) dalam mata kuliah kewirausahaan sebaiknya lebih banyak praktek dan berbagi pengalaman dari pada sekedar pemaparan teori. Hal ini selaras dengan pendapat Budhi Hendarto (2012) bahwa materi yang diajarkan dalam kewirausahaan seharusnya selain diajarkan teori juga ditekankan pada praktek. Oleh sebab itu, dari kurikulum kewirausahaan terdapat indikator selain mengajarkan teori juga menekankan pada praktek.

\section{Kajian Literatur}

Menurut Yanto, minat wirausaha adalah kemampuan untuk memberanikan diri dalam memenuhi kebutuhan hidup serta memecahkan permasalahan hidup, memajukan usaha atau menciptakan usaha baru dengan kekuatan yang ada pada diri sendiri. Hal yang paling utama yaitu sifat keberanian untuk menciptakan usaha baru.

Menurut Santoso, minat wirausaha adalah gejala psikis untuk memusatkan perhatian dan berbuat sesuatu terhadap wirausaha itu dengan perasaan senang karena membawa manfaat bagi dirinya. Inti dari pendapat tersebut adalah pemusatan perhatian yang disertai rasa senang (Maman Suryamannim, 2006: 22). Penelitian Aris Subandono (2007: 18), minat wirausaha adalah kecenderungan hati dalam diri subjek untuk tertarik menciptakan suatu usaha yang kemudian mengorganisir, mengatur, menanggung risiko dan mengembangkan usaha yang diciptakannya tersebut. Minat wirausaha berasal dari dalam diri seseorang untuk menciptakan sebuah bidang usaha. 
Berdasarkan definisi di atas, maka yang dimaksud dengan minat wirausaha adalah keinginan, ketertarikan serta kesediaan untuk bekerja keras atau berkemauan keras dengan adanya pemusatan perhatian untuk berusaha memenuhi kebutuhan hidupnya tanpa merasa takut akan resiko yang akan dihadapi, senantiasa belajar dari kegagalan yang dialami, serta mengembangkan usaha yang diciptakannya. Minat wirausaha tersebut tidak hanya keinginan dari dalam diri saja tetapi harus melihat ke depan dalam potensi mendirikan usaha.

Amin Hamzah Nasution (1993: 47), mengemukakan 5 cara meningkatkan minat, yaitu:

a. Motivasi

Motivasi adalah sesuatu dari diri seseorang yang mendorong untuk berbuat sesuatu dalam mencapai tujuan. Cara menimbulkan dorongan bisa melalui penerangan segi-segi yang baik terhadap hal-hal yang berhubungan dengan citicita ataupun apa yang diharapkan.

b. Training

Training adalah mengingat kembali semangat untuk meningkatkan ilmu dan ketrampilan serta memperbaiki adanya masalah-masalah untuk dapat berbuat lebih baik lagi.

c. Rangsangan dari luar juga dapat dipergunakan sebagai alat untuk membangkitkan minat.

d. Menanamkan kesadaran dengan adanya suatu peringatan agar selalu sadar untuk berminat.

e. Kebiasaaan dengan cara membiasakan diri untuk melakukan kegiatan agar dapat menimbulkan minat.

Evita Singgih (2006: 88), menjelaskan ada 3 cara untuk meningkatkan minat, yaitu:

a. Pemberian Ganjaran

Pemberian ganjaran untuk memperkuat perilaku individu. Prinsip dasar dari cara ini adalah teori belajar yang berpandangan bahwa kegiatan yang lebih disenangi dapat menjadi ganjaran positif, yang dapat dipakai sebagai ganjaran untuk kegiatan lain yang kurang disenangi.

Berdasarkan paparan tersebut, ganjaran bukan hukuman untuk menjatuhkan tetapi untuk membangun yang diharapkan melalui pemberian ganjaran seseorang dapat mengembangkan minat wirausahanya secara berkelanjutan.

b. Penetapan Sasaran

Penetapan sasaran sebagai sesuatu yang hendak dicapai, misalnya menyelesaikan tugas dengan tepat waktu. Makin jelas spesifik sasaran yang hendak dicapai maka akan lebih besar kemungkinan untuk mencapainya. Selain itu, perlu adanya penetapan prioritas yang hendak dicapai.

Berdasarkan paparan tersebut, dalam penetapan sasaran harus jelas agar sasaran yang akan dicapai akan mudah tercapai. Penetapan sasaran merupakan salah satu hal untuk mencapai sebuah hasil yang maksimal.

c. Penataan Lingkungan 
Penataan disini termasuk lingkungan fisik maupun lingkungan sosial. Lingkungan fisik berkaitan dengan tempat atau ruangan termasuk sarana lainnya.

Berdasarkan paparan tersebut, lingkungan yang ditata sebaik mungkin akan membantu mencapai tujuan dan penataan lingkungan merupakan sarana pendukung. Jika lingkungan tidak tertata dengan baik dapat menghambat peningkatan minat.

Berdasarkan definisi di atas, minat dapat ditingkatkan melalui motivasi agar ada dorongan untuk mencapai tujuan, training sebagai latihan ketrampilan, rangsangan dari luar untuk membangkitkan minat, menanamkan kesadaran agar sadar akan minat yang dimiliki, membiasakan diri untuk melakukan kegiatan yang akan menimbulkan minat, pemberian ganjaran untuk mengembangkan minat, menetapkan sasaran agar tujuan akan mudah tercapai, dan menata lingkungan untuk mendukung peningkatan minat.

Minat pada hakekatnya merupakan sebab akibat dari pada pengalaman, minat berkembang sebagai hasil dari pada sesuatu kegiatan yang akan menjadi sebab yang akan dipakai lagi dalam kegiatan yang sama.

Menurut L. D Crow (Agatha Dita Kristsada, 2010: 19-20), menyebutkan faktor yang mempengaruhi minat:

a. The factor inner urge adalah rangsangan yang datang dari lingkungan atau ruang lingkup yang sesuai dengan keinginan atau kebutuhan seseorang akan mudah menimbulkan minat.

b. The factor of social motive adalah minat seseorang terhadap obyek atau sesuatu hal, disamping hal dipengaruhi oleh faktor dari dalam diri manusia juga dipengaruhi oleh motif sosial.

c. Emotional factor adalah faktor perasaan dan emosi mempunyai pengaruh terhadap obyek misal perjalanan sukses yang dipakai individu dalam suatu kegiatan tertentu dapat membangkitkan perasaan senang dan dapat menambah semangat atau kuatnya minat dalam kegiatan tersebut. Minat bukan

d. merupakan suatu hal yang didapat sejak lahir, namun minat merupakan keseluruhan yang dapat berubah-ubah karena sejak kecil minat anak itu selalu mengalami perubahan. Jadi, minat dapat dikembangkan sesuai potensi pada diri seseorang.

Ilmu kewirausahaan adalah suatu disiplin ilmu yang mempelajari tentang niilai, kemampuan (ability) dan perilaku seseorang dalam menghadapi tantangan hidup untuk memperoleh peluang dengan berbagai risiko yang mungkin dihadapainya.

Kewirausahaan memiliiki pengertian yang berbeda-beda menurut para ahli, beberapa definisi tentang kewirausahaan dalam Suryana (2006:46) tersebut diantaranya:

a. Menurut Wirakusumo (1997:1) Istilah kewirausahaan berasal dari terjemahan "Enterpreneurship", yang dapat diartikan sebagai "the backbone of economy", yaitu syaraf pusat perekonomian atau sebagai "tailbone of economy", yaitu pengendalian perekonomian suatu bangsa. 
b. Menurut Ahmad Sanusi (1994) Kewirausahaan adalah suatu nilai yang diwujudkan dalam perilaku yang dijadikan dasar sumber daya, tenaga penggerak, tujuan, siasat, kiat, proses, dan hasil bisnis.

c. Menurut Thomas W Zimmerer (1996:51) kewirausahaan adalah "applyingcreativity and innovation to solve the problems and to exploit opportunities that people face everyday". Kewirausahaan adalah penerapan, kreativitas dan keinovasian untuk memecahkanpermasalahan danupaya untuk memanfaatkan peluang yang dihadapi setiap hari.

Menurut L.D Crow dalam Kristsada (2010:29-30), menyebutkan faktor yang mempengaruhi minat:

a. The factor inner urge adalah rangsangan yang datang dari lingkungan atau ruang lingkup yang sesuai dengan keinginan atau kebutuhan seseorang akan mudah menimbulkan minat.

b. The factor of social motive adalah minat seseorang terhadap obyek atau sesuatu hal, disamping hal dipengaruhi oleh faktor dari dalam diri manusia juga dipengaruhi oleh motif sosial.

c. Emotional factor adalah faktor perasaan dan emosi mempunyai pengaruh terhadap obyek misal perjalanan sukses yang dipakai individu dalam suatu kegiatan tertentu dapat membangkitkan perasaan senang dan dapat menambah semangat atau kuatnya minat dalam kegiatan tersebut.

Alma (2011:9) menyatakan terdapat 3 (tiga) faktor kritis yang berperan dalam minat berwirausaha tersebut yaitu:

a. Personal, menyangkut aspek-aspek kepribadian seseorang

b. Socialogical, menyangkut masalah hubungan dengan family dan hubungan sosial lainnya

c. Environmental, menyangkut hubungan dengan lingkungan

Indikator dari minat berwirausaha menurut Alma (2010:53) adalah

a. Percaya diri.

b. Berorientasi pada tugas dan hasil.

c. Berani mengambil resiko.

d. Berjiwa kepemimpinan

e. Keorisinilan

f. Berorientasi ke masa depan.

Berdasarka penjelasan diatas, maka konsep/kerangka pikir dalam penelitian adalah sebagai berikut:

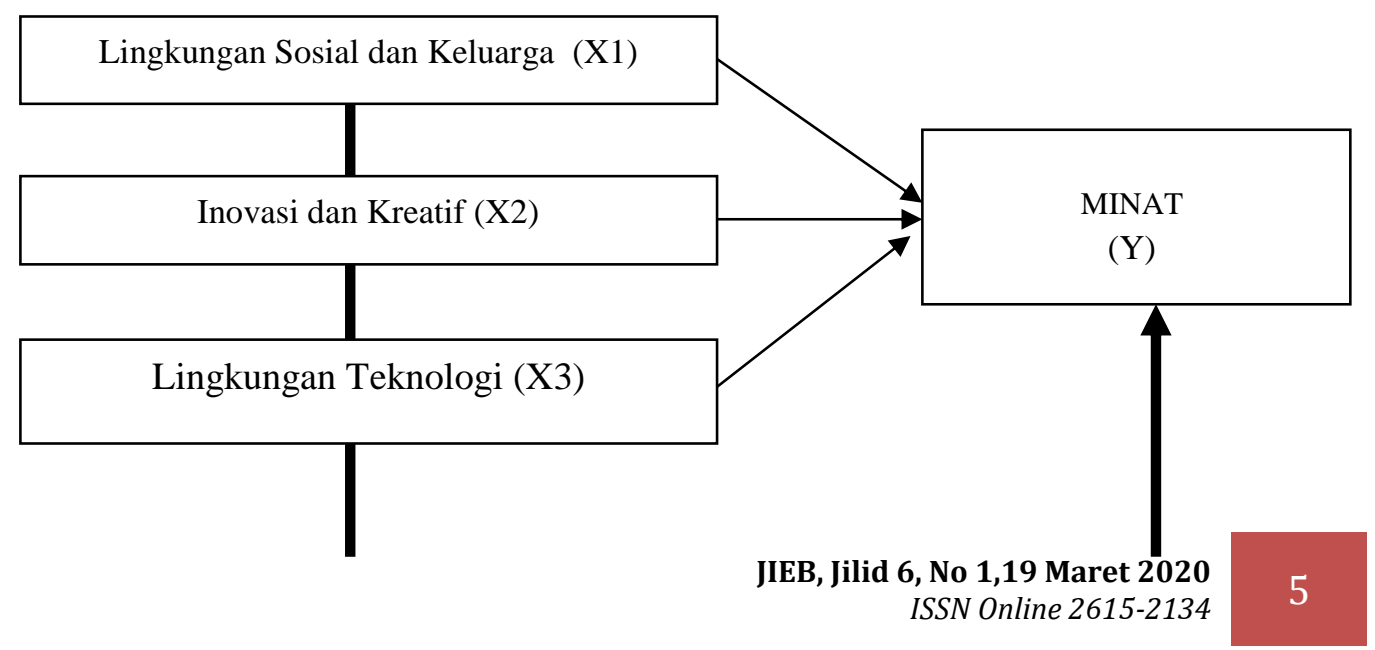




\section{Keterangan: $\longrightarrow$ Pengaruh Secara Parsial \\ $\longrightarrow$ Pengaruh Secara Simultan}

Gambar: Kerangka Konseptual dan Hipotesis

\section{Metode Penelitian}

Penelitian ini adalah penelitian kuantitatif. Penelitian kuantitatif digunakan untuk meneliti pada populasi atau sampel tertentu. Penggunan penelitian kuantitatif bertujuan untuk mengetahui faktor-faktor yang mempengaruhi minat berwirausaha pada mahasiswa jurusan manajemen fakultas ekonomi universitas islam Kalimantan Muhammad arsyad al-banjary Banjarmasin.

Dalam rangka memperoleh data untuk penelitian ini digunakan teknik pengumpulan data adalah Observasi, Dokumentasi, Kuisioner. Sebelum dilakukan pengujian dengan analisis regresi, data penelitian diuji dengan uji asumsi klasik yang terdiri dari : uji normalitas, uji heterokedastisitas, dan uji multikolonieritas. Kemudian untuk pengujian hipotesis secara simultan menggunakan Uji F, dan untuk pengujian hipotesis secara parsial menggunakan Uji t. Sedangkan untuk menentukan variabel yang paling dominan mempengaruhi tingkat kepuasan kerja karyawan menggunakan nilai standrdized coefficient beta.

\section{Hasil Penelitian dan Pembahasan}

Langkah pertama dalam analisis ini adalah melakukan uji validitas dan reliabilitas. Penelitian ini dinyatakan valid dan reliabel seperti ditunjukkan pada Tabel 1 dan 2

\section{Tabel 1 Rangkuman Hasil Uji Tes Validitas Kuisioner}

\begin{tabular}{|c|c|c|c|c|c|}
\hline Variabel & Indikator & $\begin{array}{l}\text { Corrected item-total } \\
\text { correction }\left(\mathrm{r}_{\text {hitung }}\right)\end{array}$ & $\langle>$ & $\mathrm{r}_{\text {tabel }}$ & Keterangan \\
\hline \multirow{3}{*}{$\begin{array}{c}X 1 \\
\text { Lingkungan Sosial } \\
\text { Dan Keluarga }\end{array}$} & $\mathrm{X} 1.1$ & .856 & $>$ & 0.000 & Valid \\
\hline & $\mathrm{X} 1.2$ & .710 & $>$ & 0.000 & Valid \\
\hline & $\mathrm{X} 1.3$ & .830 & $>$ & 0.000 & Valid \\
\hline \multirow{3}{*}{$\begin{array}{c}X 2 \\
\text { Inovasi dan Kreatif }\end{array}$} & X.2.1 & .789 & $>$ & 0.000 & Valid \\
\hline & $\mathrm{X} 2.2$ & .734 & $>$ & 0.000 & Valid \\
\hline & $\mathrm{X} 2.3$ & .796 & $>$ & 0.000 & Valid \\
\hline \multirow{3}{*}{$\begin{array}{c}X 3 \\
\text { Lingkungan Teknologi }\end{array}$} & X3.1 & .873 & $>$ & 0.000 & Valid \\
\hline & X3.2 & .757 & $>$ & 0.000 & Valid \\
\hline & X3.3 & .826 & $>$ & 0.000 & Valid \\
\hline
\end{tabular}

Sumber: Data Yang Diolah, Tahun 2019.

Berdasarkan dari uji validitas menunjukkan bahwa nilai $r_{\text {hitung }}$ lebih besar dibanding nilai $\mathrm{r}_{\text {tabel. }}$. Dengan hasil ini maka kuesioner yang digunakan oleh variabel $\mathrm{X} 1, \mathrm{X} 2$ dan $\mathrm{X} 3$ dinyatakan valid sebagai alat ukur variabel.

\section{Tabel 2 Hasil Uji Reliabilitas}

\begin{tabular}{|c|c|c|c|c|}
\hline Variabel & Hasil Cronbach Alpha & $><$ & Standar Reliabilitas & Keterangan \\
\hline
\end{tabular}




\begin{tabular}{|c|c|c|c|c|}
\hline $\begin{array}{c}\text { Lingkungan Sosial Dan } \\
\text { Keluarga } \\
\text { (X1) }\end{array}$ & .860 & $>$ & 0.60 & Reliabel \\
\hline $\begin{array}{c}\text { Inovasi dan Kreatif }(\mathrm{X} 2) \\
\begin{array}{c}\text { Lingkungan Teknologi } \\
(\mathrm{X} 3)\end{array}\end{array}$ & .826 & $>$ & 0.60 & Reliabel \\
\hline
\end{tabular}

Sumber: Data Yang Diolah, Tahun 2019.

Berdasarakan hasil uji reliabilitas menunjukkan nilai cronbach's alpha variabel $\mathrm{X}$ di atas 0,60. Hal ini berarti kuesioner dari masing-masing indikator terbukti dapat dipercaya untuk digunakan sebagai alat ukur variabel.

Langkah selanjutnya adalah melakukan uji asumsi klasik, dengan urutan pengujian sebagai berikut:

\section{Linieritas}

Pengujian linieritas dalam penelitian ini menggunakan dilakukan dengan analisis grafik Normal P.P of Regression Standardized Residual. Jika terdapat gejala bahwa letak gejala titik-titik (data) itu ada pada atau menyebar sekitar garis lurus diagonalnya, maka cukup menjadi alas an bahwa antara variabelvariabel tersebut terdapat hubungan linier. Hasil uji linieritas pada penelitian ini dapat dilihat pada grafik berikut:

\section{Gambar Grafik Hasil Uji Linieritas}

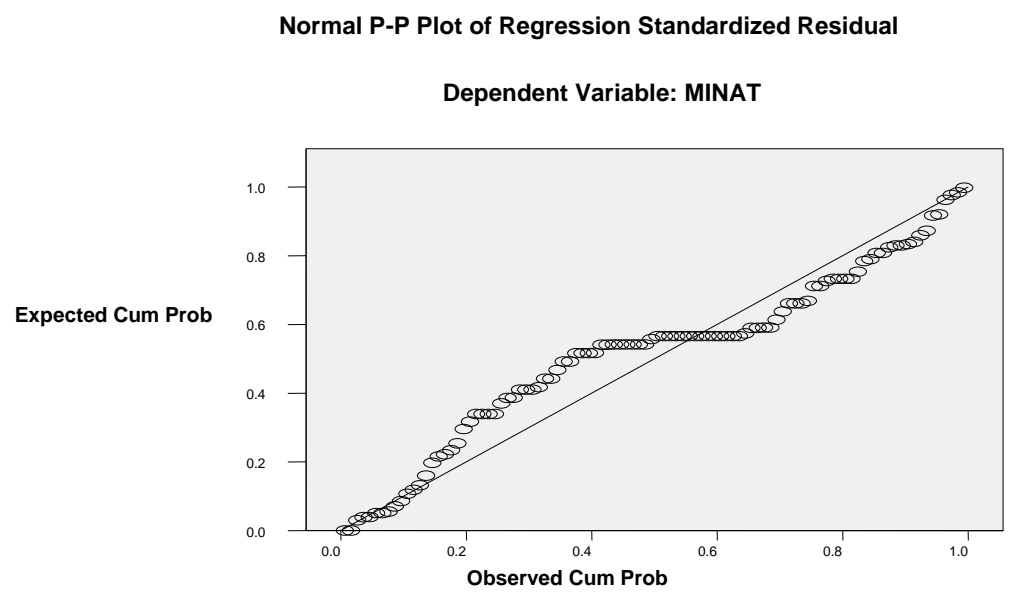

Sumber: Data Primer Yang Diolah 2019.

Berdasarkan grafik diatas maka dapat disimpulkan bahwa plot data menyebar sekitar garis lurus mengikuti garis diagonalnya. Dengan demikian dapat diartikan bahwa terdapat adanya hubungan linier antara variabel-variabel bebas dengan variabel terikat.

\section{Uji Multikolinieritas}

Hasil uji Multikolinearitas ditunjukkan pada Tabel 3. Karena nilai VIF dari masing-masing variabel bebas semuanya dibawah 5 , maka penelitian ini bebas masalah multikolinearitas.

\section{Tabel 3 Hasil Uji Multikolinieitas}

\section{Coefficients(a)}




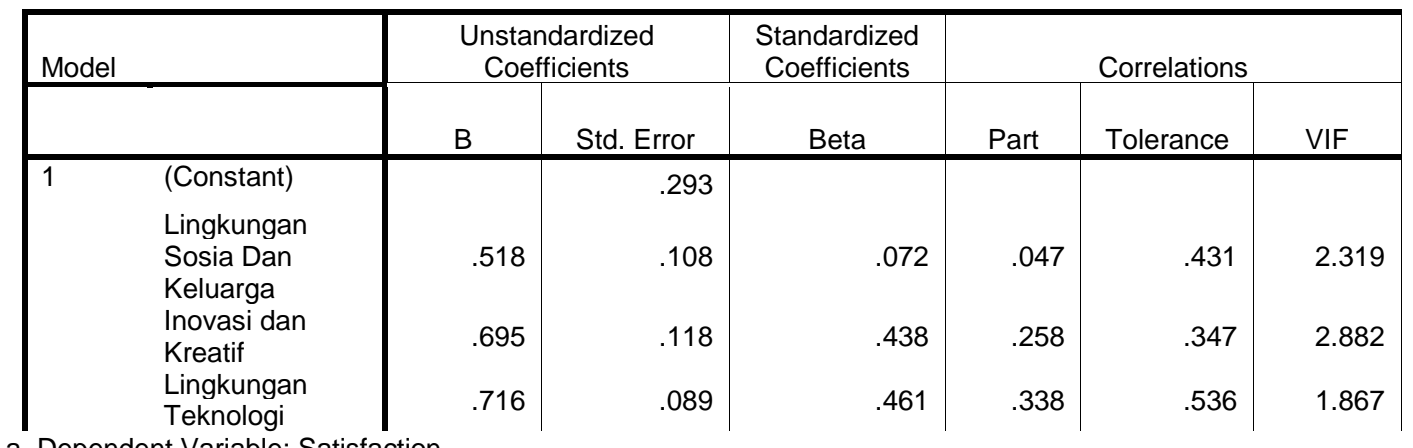

a Dependent Variable: Satisfaction

Sumber: Data Yang Diolah Tahun 2019.

Berdasarkan tabel diatas, maka dapat disimpulkan bahwa variabel yang mempengaruhi minat mahasiswa untuk berwirausaha terutama variabel Lingkungan social dan keluarga (X1) memiliki nilai toleransi 0,431 dengan VIF sebesar 2.319, Variabel Inovasi dan Kreatif (X2) memiliki nilai tolerance 0.347 dengan VIF sebesar 2.882 serta variabel Lingkungan teknologi (X3) memiliki nilai tolerance 0.536 dengan VIF sebesar 1.867 . Dengan demikian, dapat disimpulkan bahwa ketiga variabel memiliki nilai VIF kurang dari 10 dan nilai tolerance diatas 0,1 maka dapat disimpulkan tidak terjadi multikolinieritas.

\section{Tabel 4 Hasil Uji Regresi Linier Berganda}

\begin{tabular}{|c|c|c|c|c|c|c|}
\hline \multicolumn{2}{|c|}{ Model } & \multicolumn{2}{|c|}{$\begin{array}{l}\text { Unstandardized } \\
\text { Coefficients }\end{array}$} & \multirow{2}{*}{$\begin{array}{c}\text { Standardized } \\
\text { Coefficients } \\
\text { Beta }\end{array}$} & \multirow[b]{2}{*}{$t$} & \multirow[b]{2}{*}{ Sig. } \\
\hline & & $\mathrm{B}$ & Std. Error & & & \\
\hline \multirow[t]{4}{*}{1} & (Constant) & .554 & .293 & & 1.892 & .062 \\
\hline & $\begin{array}{l}\text { Lingkungan Sosial dan } \\
\text { Keluarga }\end{array}$ & -.079 & .108 & -.072 & -.731 & .466 \\
\hline & Inovasi dan Kreatif & .469 & .118 & .438 & 3.984 & .000 \\
\hline & Lingkungan Teknologi & .463 & .089 & .461 & 5.214 & .000 \\
\hline
\end{tabular}

a Dependent Variable: Satisfaction

Sumber: Data Yang Diolah Tahun 2019.

Dari tabel 4 maka persamaan Regresi yang terbentuk adalah sebagai berikut: $\mathbf{Y}=\mathbf{0 , 5 5 4}+(-\mathbf{0 , 0 7 9} \mathrm{X1})+\mathbf{0 , 4 6 9} \mathrm{X} 2+\mathbf{0 , 4 6 3} \mathrm{X3}+\mathbf{e}$. Hasil dari analisis tersebut dapat diinterprestasikan sebagai berikut: 0,554 , artinya bahwa variabel yang mempengaruhi terhadap minat mahasiswa sama dengan nol maka minat mahasiswa untuk berwirausaha akan naik sebesar 0,554 satuan atau naik sebesar 55.4\%. 0,079, artinya bahwa apabila faktor lingkungan sosial dan keluarga yang mempengaruhi minat mahasiswa untuk berwirausaha (X1), maka maka rata-rata minatnya akan naik sebesar kurang dari - 0.079 satuan atau hanya akan berpengaruh sebesar $0.97 \%$, sedangkan variabel lain konstan. 0,469, artinya bahwa apabila faktor Inovasi dan kreatif yang mempengaruhi minat mahasiswa untuk berwirausaha (X2), maka rata-rata minatnya akan naik sebesar 0,469 satuan, sedangkan variabel lain konstan. 0,463, artinya bahwa apabila faktor Lingkungan Teknologi yang mempengaruhi minat mahasiswa untuk berwirausaha (X3), maka rata-rata minatnya akan naik sebesar 0,463 satuan, sedangkan variabel lain konstan. 
Tabel 5 Hasil Uji t

Coefficients(a)

\begin{tabular}{|c|c|c|c|c|c|c|}
\hline \multicolumn{2}{|c|}{ Model } & \multicolumn{2}{|c|}{$\begin{array}{l}\text { Unstandardized } \\
\text { Coefficients }\end{array}$} & \multirow{2}{*}{$\begin{array}{c}\text { Standardized } \\
\text { Coefficients } \\
\text { Beta }\end{array}$} & \multirow[b]{2}{*}{$t$} & \multirow[b]{2}{*}{ Sig. } \\
\hline & & B & Std. Error & & & \\
\hline \multirow[t]{4}{*}{1} & (Constant) & .554 & .293 & & 1.892 & .062 \\
\hline & $\begin{array}{l}\text { Lingkungan Sosial dan } \\
\text { Keluarga }\end{array}$ & -.079 & .108 & -.072 & -.731 & .466 \\
\hline & Inovasi dan Kreatif & .469 & .118 & .438 & 3.984 & .000 \\
\hline & Lingkungan Teknologi & .463 & .089 & .461 & 5.214 & .000 \\
\hline
\end{tabular}

a Dependent Variable: Satisfaction

Sumber: Data Yang Diolah Tahun 2019.

Dari hasil rangkuman nilai T signifikan pada tabel 4.8 diatas terlihat bahwa, Variabel X2 (Inovasi dan Kreatif) nilai signifikan T lebih besar dari 5\% yaitu 3.984 dengan angka sig 0.000. Untuk Variabel X3 (Lingkungan Teknologi) nilai signifikan T lebih besar dari 5\% yaitu 5.214 dengan angka sig. 0.000. Jadi variabel X2 dan X3 signifikan dalam mempengaruhi Y (Minat) atau $\mathrm{H}_{0}$ ditolak dan $\mathrm{H}_{\mathrm{a}}$ diterima. Sedangkan untuk Lingkungan Sosial dan Kelurga tidak berpengaruh terhadap minat mahasiswa untuk berwirausaha karena nilai signifikan T kurang dari 5\%. Sutrisno Hadi (1996) dalam penjelasannya mengenai kaidah uji hipotesis penelitian, jika hasil peluang ralat $(\mathrm{p})<0,15$ hasilnya dikategorikan cukup signifikan artinya $\mathrm{H}_{0}$ ditolak dan $\mathrm{H}_{\mathrm{a}}$ diterima.

\section{Pembahasan Hasil Penelitian}

\section{Hubungan Antara Lingkungan Sosial dan Keluarga Dengan Minat Berwirausaha}

Lingkungan sosial yang mayoritas para wirausahawan akan sangat memengaruhi minat berwirausaha seseorang karena lingkungan sosial tersebut akan membawa seseorang untuk membangun suatu jaringan yang dapat membantunya dalam proses memulai usaha (Kadarsih, 2013). Faktor lingkungan sosial dalam penelitian ini meliputi profesi teman yang memotivasi timbulnya minat berwirausaha.

Dalam penelitian ini menunjukan bahwa lingkungan sosial dan keluarga tidak dapat mempengaruhi terhadap minat berwirausaha dengan tingkat probabilitas kurang dari 0,05 atau kurang dari $5 \%$.

\section{Hubungan Inovasi dan Kreatifitas Dengan Minat Berwirausaha}

Kewirausahaan adalah suatu kemampuan kreatif dan inovatif dalam menciptakan sesuatu yang baru dan berbeda yang dijadikan dasar, kiat dalam usaha atau perbaikan hidup. Hakikat dasar dari kewirausahaan adalah kreatifitas dan inovasi (Suryana, 2006).

Dalam penelitian ini menunjukan bahwa Inovasi dan Kreatifitas berpengaruh positif terhadap minat berwirausaha dengan masing-masing tingkat probabilitas sebesar 0.469 atau sebesar $46.9 \%$. Jadi dapat disimpulkan bahwa inovasi dan kreatifitas berpengaruh terhadap minat berwirausaha. 


\section{Hubungan Antara Lingkungan Teknologi Dengan Minat Berwirausaha}

Kemajuan teknologi dan fasilitas saat ini seperti televisi, telepon dan telepon genggam (HP), bahkan internet. Saat ini dapat kita lihat betapa kemajuan teknologi telah mempengaruhi gaya hidup dan pola pikir masyarakat, terutama di kalangan remaja (Ibnu, 2013).

Dapat ditarik kesimpulan bahwa kecanggihan teknologi serta fasilitas yang ada dapat mempengaruhi gaya hidup seseorang. Adanya internet dapat membantu menyampaikan informasi dengan cepat, dengan begitu banyak pengusaha yang memanfaatkan teknologi untuk berbisnis dan dengan adanya internet mempermudah siapa saja untuk melakukan kegiatan bisnis dengan contoh kecil berjualan melalui internet.

Senada dengan hal tersebut diatas, dalam penelitian ini menunjukan bahwa teknologi dan fasilitas berpengaruh positif terhadap minat berwirausaha dengan tingkat probabilitas sebesar 0.463 atau sebesar $46.3 \%$. Jadi dapat disimpulkan bahwa teknologi dan fasilitas berpengaruh terhadap minat berwirausaha.

Dari hasil analisis yang dilakukan, diperoleh bahwa faktor-faktor yang mempengaruhi terhadap minat, secara siginifikan berpengaruh dan perubahannya berubah searah dengan minat untuk dapat berwirausaha. Artinya jika tingkat pengaruh ketiga variabel dapat dirasakan oleh para mahasiswa makin tinggi, maka mengakibatkan makin tinggi juga tingkat minatnya untuk dapt berwirausaha.

Persamaan regresi yang didapat dari hasil analisis tersebut adalah:

$\mathrm{Y}=\mathbf{0 , 5 5 4}+(-\mathbf{0 , 0 7 9} \times 1)+\mathbf{0 , 4 6 9} \mathrm{X2}+\mathbf{0 , 4 6 3} \mathrm{X3}+\mathrm{e}$

Untuk melihat dominasi pengaruh dari variabel bebas terhadap variabel terikatnya, maka bisa dilihat koefisien beta (koefisien regresi baku). Nilai koefisien regresi baku antar variabel bebas dapat dibandingkan, karena nilainya telah distandarisasi sehingga variabel bebas yakni Variabel lingkungan social dan kelurga (X1) inovasi dan kreatif (X2) dan lingkungan teknologi (X3) memiliki koefisien regresi baku yang lebih besar, berarti akan memberi pengaruh yang lebih besar pula pada variabel terikatnya.

Implikasi hasil uji $\mathrm{F}$ bagi perguruan tinggi dan tenaga pengajar ahli dalam hal ini adalah dosen jika ingin meningkatkan tingkat minat mahasiswa untuk dapat berwirausaha maka perlu menekankan pada ketiga faktor tersebut yaitu berturutturut Variabel lingkungan social dan kelurga (X1) inovasi dan kreatif (X2) dan lingkungan teknologi (X3). Hal ini harus dilakukan secara terus menerus (continues improvement) dalam usaha untuk meningkatkan minat mahasiswa untuk berwirausaha.

Untuk mendukung keterangan diatas dapat juga kita lihat hasil $\mathrm{R}^{2}$ (Koefisien Determinasi) Regresi yaitu sebesar 0,773 atau 73,3\%. Hal ini dapat diartikan bahwa sebanyak 73,3\% Tingkat minat mahasiswa untuk berwirausaha dijelaskan oleh ketiga faktor yang mempengaruhi minat berwirausaha. Sedangkan sisanya sebesar $26.7 \%$ dijelaskan oleh variabel lain diluar variabel yang dapat mempengaruhi terhadap minat mahasiswa untuk dapat berwirausaha.

\section{Kesimpulan dan Saran}


Dari hasil analisis yang dilakukan, diperoleh bahwa faktor-faktor yang mempengaruhi terhadap minat, secara siginifikan berpengaruh dan perubahannya berubah searah dengan minat untuk dapat berwirausaha. Artinya jika tingkat pengaruh ketiga variabel dapat dirasakan oleh para mahasiswa makin tinggi, maka mengakibatkan makin tinggi juga tingkat minatnya untuk dapt berwirausaha. Persamaan regresi yang didapat dari hasil analisis tersebut adalah: $\mathbf{Y}=\mathbf{0 , 5 5 4}+$ ($0,079 \times 1)+0,469 \times 2+0,463 \times 3+$ e. Untuk melihat dominasi pengaruh dari variabel bebas terhadap variabel terikatnya, maka bisa dilihat koefisien beta (koefisien regresi baku). Nilai koefisien regresi baku antar variabel bebas dapat dibandingkan, karena nilainya telah distandarisasi sehingga variabel bebas yakni Variabel lingkungan social dan kelurga (X1) inovasi dan kreatif (X2) dan lingkungan teknologi (X3) memiliki koefisien regresi baku yang lebih besar, berarti akan memberi pengaruh yang lebih besar pula pada variabel terikatnya.

Adapun saran yang perlu direkomendasikan dalam penelitian ini yakni Jika dilihat dari hasil analisis dan kesimpulan diatas bahwa setiap mahasiswa sebenarnya sangat antusias untuk dapat berwirausaha akan tetapi dari 100 orang responden terlihat bahwa untuk lingkungan teknologi sangat besar pengaruhnya terhadap minat berwirausaha. Artinya lingkungan teknologi disini perlu kita tingkatkan terutama bagi dosen ataupun pengajar serta pengaruh lingkungan social juga hendaknya kita tingkatkan.Untuk dapat meningkatkan kepercayaan diri mahasiswa sekiranya kita perlu memberikan motivasi dan gambaran secara luas tentang berwirausaha melalui pemberian mata kuliah kewirausahaan yang efektif, melakukan pelatihan-pelatihan dan lain sebagainya.

\section{DAFTAR USTAKA}

Alma, Buchari. (2010) Kewirausahaan (edisi revisi). Bandung: CV Alfabeta.,

Aris et al. (2013). Analisis Kepemilikan Jiwa wirausaha Pada Pelaku Usaha Kecil dan Menengah di Kota Depok. Bandung: Proceding PESAT (Psikologi, EKonomi, Sastra, Arsitektur \& Teknik Sipil). Vol. 5 Oktobers 2013. ISSN: $1858-2559$

Ayuningtyas et al. (2015). Faktor-faktor yang mempengaruh Minat Berwirausaha Pada Mahasiswa Fakultas Ekonomi Universitas Tarumanegara. Jurnal Ekonomi: Volume XX, No. 01, Maret 2015.

Djaali. (2007). Psikologi pendidikan. Jakarta: Bumi Aksara. Fuadi, I.F. 2009. Hubungan minat berwirausaha dengan prestasi praktikkerja industri siswa kelas XII teknikotomotif SMK Negri 1 Adiwerna Kabupaten Tegal.” Jurnal PTM 9(1) Desember: 92-98.

Fatrika et al. Analisis Faktor-Faktor Yang Mempengaruhi Minat Wirausaha Mahasiswa Dengan Teknik SEM. Jurnal Matematika UNAND Vol. 1 No. 2 Hal. 5-12. ISSN 2303.2910

Koranti, Komsi. (2013). Analisis Pengaruh Faktor Eksternal dan Internal Terhadap Minat Berwirausaha. Bandung: Proceding PESAT (Psikologi, Ekonomi, Sastra, Arsitektur \& Teknik Sipil). Vol. 5 Oktober 2013. ISS: 1858-2559.

Praswati, Aflit N. (2014). Analisis Faktor-faktor Yang Mempengaruhi Minat Wirausaha Di Kalangan Mahasiswa Studi Kasus: Fakultas Ekonomika dan 
Bisnis Universitas Muhammadiyah Surakarta. Seminar Nasional dan Call for Paper (Sancall 2014). ISBN: 978-602-70429-1-9.

Periyadi, Junaidi (2018), Pengaruh Faktor Internal Dan Eksternal Terhadap Minat Berwirausaha Pada Mahasiswa Fakultas Ekonomi Universitas Islam Kalimantan (Uniska) Muhammad Arsyad Al-Banjary Banjarmasin, Dinamika Ekonomi Jurnal Ekonomi dan Bisnis (ISSN 1693 - 8623) Vol I 1. No.2 September 2018.

Rosmiati et al. (2015) Sikap, Motivasi dan Minat Berwirausaha Mahasiswa. JMK. Vol 17 No. 1 Maret 2015

Subandono, A. (2007). Pengaruh Life Skill Diklat Kimia Produktif dan Prestasi Belajar Diklat Kewirausahaan terhadap Minat Berwirausaha pada Siswa SMK Kimia Industri Theresiana Semarang. Skripsi.FMIPA-UNES

Sugiyono (2007). Metode penelitian pendidikan, pen-dekatan kuantitatif, kualitatif, dan $R \& D$. Ban-dung: Alfabeta

Suryana. (2006). Kewirausahaan Edisi 3. Jakarta: Salemba Empat. 